\title{
Musik Semar Pegulingan Menurunkan Kecemasan Pasien Pre Operasi di Ruang Persiapan Siloam Hospitals Bali
}

\author{
Ni Putu Dian Yuniantari', I Wayan Artana ${ }^{2}$, I Nyoman Sutresna ${ }^{3}$
}

\author{
STIKES Bina Usada Bali
}

putuyuyun66@gmail.com

Kecemasan pasien sebelum operasi dapat mengganggu jalannya pembedahan bahkan pasien bisa membatalkan tindakan yang akan dilakukan. Terapi musik tradisional semar pegulingan dapat dipakai sebagai alternatif menurunkan kecemasan. Studi bertujuan untuk memahami bagaimana pengaruh musik semar pegulingan terhadap kecemasan pasien pre operasi di ruang persiapan Siloam Hospitals Bali. Menggunakan metode kuantitatif, desain pre eksperimental pretestposttest with control. Sampelnya pasien pre operasi yang mengunakan lokal anastesi, dipilih secara purposive sampling, berjumlah 32 orang. Sampel dibagi menjadi kelompok perlakuan dan kelompok kontrol masing-masing 16 orang, dipilih secara simpel random sederhana. Data pretest dan posttest dianalisis menggunakan uji Wilcoxon, sedangkan data antar kelompok menggunakan uji Mann Whitney pada a 0.05. Pada kelompok intervensi rerata kecemasan pre adalah 21,12 dan post 15,75 dengan $\mathrm{p}(0,001<\alpha(0,05)$. Pada kelompok pre test 21.81 dan post test 18.50 dengan $\mathrm{p}$ $(0,001<\alpha(0,05)$. Hasil uji Mann Whitney pre test pada kelompok kontrol dan intervensi didapatkan nilai $p$ value $(0.153)>(0.05)$ dan setelah dilakukan intervensi didapatkan $p$ value $(0.01)<\alpha(0,05)$. Musik semar pegulingan mampu menurunkan kecemasan pada pasien preoperatif. Diharapkan terapi musik semar pegulingan diperdengarkan pada pasien pre operasi untuk menurunkan kecemasannya.

Kata kunci: kecemasan, pre operasi, musik semar pegulingan

Patients' anxiety before surgery can interfere the operation even the patients can cancel the action to be performed. Semar pegulingan traditional music therapy can be used as an alternative to reduce anxiety. The study aimed to understand how the effect of Semar pegulingan music on anxiety levels of presurgery patients in the Preparation Ward of Siloam Hospitals Bali. This study used quantitative methods, pre-experimental pretest-posttest with control design. The sample was presurgery patients using local anesthesia, selected by purposive sampling of 32 people. The sample was divided into a treatment and a control group each consisted of 16 people, selected by simple random. The pretest and posttest data were analyzed using Wilcoxon test, while the data between groups used Mann Whitney test at a 0.05 . In the intervention group, the average of pre-anxiety level was 21.12 and 15.75 with $\mathrm{p}$ (0.001 < $\alpha$ (0.05). In the pre-test group, 21.81 and 18.50 in the post-test group, $\mathrm{p}(0.001<\alpha(0.05)$. Mann Whitney pre-test in the control and intervention groups obtained $p$ value (0.153)> (0.05) and after the intervention obtained $\mathrm{p}$ value (0.01) < $\alpha(0.05)$. Semar pegulingan music can reduce anxiety in presurgery patients. It is expected that semar pegulingan music is played in presurgery patients to reduce anxiety.

Keywords: anxiety, presurgery, semar pegulingan music 


\section{PENDAHULUAN}

Kecemasan pada pasien pre operasi biasanya berhubungan dengan segala macam tindakan dan juga ancaman terhadap keselamatan jiwa akibat prosedur pembedahan dan tindakan pembiusan (Paryanto, 2017). Data dari Kemenkes RI (2018) memunjukkan prevalensi ganggunan mental emosional yang ditunjukkan dengan gejala-gejala depresi dan kecemasan untuk usia 15 tahun ke atas mencapai sekitar $6,1 \%$ dari jumlah penduduk Indonesia meningkat $0,1 \%$ dari data tahun 2013 dengan persentase 6,0\%. Widyastut (2015) menyatakan 90\% pasien pre operasi berpotensi mengalami kecemasan. Kustiawan (2013) dalam penelitiannya juga menemukan bahwa 81,0\% pre operasi di RSU Kota Tasikmalaya mengalami kecemasan sedang.

Jumlah tindakan di ruang operasi Siloam Hospitals Bali dari tahun ke tahun selalu mengalami peningkatan, tahun 2017 tercatat 2.225 tindakan dengan rerata 185 tindakan/bulan, tahun 2018 tercatat 2.737 tindakan dengan rerata 228 tindakan/ bulan dan tahun 2019 mencapai 2862 tindakan dengan rerata 238 tindakan/ bulan (Laporan Utilisasi SHDP, 2019). Berdasarkan data yang diperoleh di ruang operasi Siloam Hospitals Bali dari 20 pasien yang akan menjalani tindakan operasi sebanyak 10\% memiliki tingkat kecemasan berat, 55,5\% memilki tingkat kecemasan sedang dan 35\% memilki tingkat kecemasan ringan.

Menurunkan kecemasan sebelum pembedahan sangatlah penting bagi pasien, karena jika tidak ditangani secara tepat dan benar maka akan muncul berbagai macam akibat di antaranya akan terjadi penundaan pembedahan (Majid, 2011). Kecemasan yang timbul menjelang tindakan juga dapat mengganggu jalannya proses operasi, yaitu dapat mempengaruhi frekuensi jantung sehingga tekanan darah dan pernafasan pasien menjadi terganggu, sehingga dapat meningkatkan resiko pendarahan baik pada saat pembedahan ataupun pasca operasi. Selain itu kecemasan dapat pula mempengaruhi dosis pemberian obat anestesi, karena meningkatknya kepekaan pasien terhadap rasa sakit (Waryanuarita, 2017).

Penelitian yang dilakukan oleh Wisuda (2018) tentang "Pengaruh Terapi Musik Terhadap Penurunan Tingkat Kecemasan Pasien Pre Operasi di
RSUD dr Sayidiman Magetan" mememukan bahwa Kecemasan pasien menurun setelah diperdengarkan musik. Waryanuarita (2017) yang meneliti tentang "Pengaruh Pemberian Terapi Musik Terhadap Kecemasan Pasien Pre General Anestesi di RS PKU Muhammadiyah Yogyakarta" juga menemukan adanya pengaruh pemberian terapi musik terhadap kecemasan pasien pre general anestesi di RS PKU Muhammadiyah Yogyakarta.

Musik adalah suatu komponen yang dinamis yang bisa memengaruhi baik psikologis maupun fisiologis bagi pendengarnya (Novita, 2012). Terapi musik klasik dapat menekan sistem saraf simpatik yang terlibat dengan penurunan respon stres tubuh. Alunan nada dalam musik klasik dapat memicu otak untuk melepaskan hormon endorfin, meningkatkan kadar dopamin, dan memblokir jalur nyeri, semuanya dapat membantu untuk meningkatkan rasa kesejahteraan dan penurunan kecemasan (Kaplan, 2010). Semar pegulingan merupakan musik klasik yang cukup terkenal di Bali. Pada zaman dahulu semar pagulingan dikenal sebagai gamelan atau musik rekreasi diistana kerajaan dan biasanya dimainkan pada waktu raja-raja akan kepraduan (tidur) karena alunan nandanya yang lembut dan suaranya yang merdu (Wayan Dibia dalam Diatmika, 2015).

Berdasarkan literature review yang dilakukan peneliti, belum pernah ada yang meneliti tentang manfaat dari mendengarkan musik klasik khas Bali padahal di Bali sendiri sangat kaya akan seni musik klasik. Bercermin dari hal tersebut maka peneliti sangat tertarik untuk melakukan penelitian tentang "pengaruh musik semar pegulingan terhadap tingkat kecemasan pasien pre operasi di Ruang Persiapan Siloam Hospitals Bali”.

\section{KAJIAN TEORITIS}

Terapi musik berdampak positif untuk mengatasi cemas dan stress karena dapat mengaktifkan sel-sel pada sistem limbik dan saraf otonom klien. Musik merupakan getaran udara harmonis yang ditangkap oleh organ pendengaran melalui saraf di dalam tubuh kita, serta disampaikan ke susunan sarah pusat (Atwater, 2011). Saat seseorang mendengarkan musik klasik, maka harmonisasi dalam musik klasik yang indah akan masuk telinga dalam bentuk suara (audio), menggetarkan gendang telinga, mengguncangkan cairan di telinga dalam serta menggetarkan sel-sel 
rambut di dalam koklea untuk selanjutnya melalui saraf koklearis menuju talamus (salah satu bagian otak yang berfungsi menerima pesan dari indara dan diteruskan kebagian otak lain), kemudian dilanjutkan ke hipokampus dan meneruskan sinyal musik ke amigdala yang merupakan area perilaku kesadaran yang bekerja pada tingkat bawah sadar, sinyal kemudian diteruskan ke hipotalamus (Ganong, 2012). Musik klasik akan memberikan kesan positif pada hipokampus dan amigdala sehingga merangsang hipotalamus untuk melepaskan hormon serotonin dan endorphin yang menyebabkan tubuh menjadi rileks dan membuat detak jantung menjadi stabil (Hayati, 2017).

Gelombang suara musik yang dihantar ke otak berupa energi listrik akan membangkitkan gelombang otak yang dibedakan atas frekuensi alfa, beta, tetha, dan delta. Gelombang alfa membangkitkan relaksasi, beta terkait dengan aktivitas mental, gelombang tetha dikaitkan dengan situasi stress, depresi dan upaya kreativitas. Sedangkan gelombang delta dikaitkan dengan situasi mengantuk. Suara musik yang didengar dapat memengaruhi frekuensi gelombang otak sesuai dengan jenis musik (Atwater, 2011).

Musik klasik yang mempunyai kategori frekuensi alfa dan tetha $5000-8000 \mathrm{~Hz}$ dapat merangsang tubuh dan pikiran menjadi rileks sehingga merangsang otak menghasilkan hormon serotonin dan endorphin yang menyebabkan tubuh menjadi rileks dan membuat detak jantung menjadi stabil (Murtisari $\mathrm{dkk}$, 2014). Serotonin merupakan zat kimia yang mentransmisikan impuls saraf di seluruh ruang antara sel-sel saraf atau neuron dan memiliki peran dalam mencegah kecemasan, muntah, dan migrain. Perubahan tingkat serotonin menjadi hormon melatonin memiliki efek regulasi terhadap relaksasi tubuh sehingga dapat memperbaiki suasana hati (mood), baik itu menciptakan suasana tenang, rileks, aman, maupun menyenangkan, sehingga mampu membuat pasien merasa nyaman (Yulinda, 2014).

Kecemasan pada pasien yang akan dilakukan tindakan operasi biasanya berhubungan dengan segala macam prosedur asing yang harus dijalani pasien dan juga ancaman terhadap keselamatan jiwa akibat prosedur pembedahan dan tindakan pembiusan (Paryanto, 2017). Kecemasan pada masa pre operasi merupakan hal yang wajar. Beberapa pernyataan yang biasanya diungkapkan misalnya, ketakutan munculnya rasa nyeri setelah pembedahan, ketakutan terjadi perubahan fisik (menjadi buruk rupa dan tidak berfungsi secara normal), takut memasuki ruang operasi, menghadapi peralatan bedah dan petugas, takut mati saat dilakukan anestesi, serta ketakutan apabila operasi akan mengalami kegagalan (Angkasa, 2018).

\section{KAJIAN EMPIRIS}

Adapun jurnal terkait yang digunakan oleh Suswanti (2019) tentang Hubungan Pengetahuan Perioperatif dengan Tingkat Kecemasan Pasien Pre Operasi Katarak di Rs Mata Dr. Yap Yogyakarta, didapatkan bahwa ada hubungan pengetahuan perioperatif dengan tingkat kecemasan pasien pre operasi katarak di RS Mata "Dr. Yap" Yogyakarta. Rahayu (2017) tentang pengaruh terapi musik klasik terhadap perubahan tingkat kecemasan pada pasien pre operasi sectio caesarea di ruang bersalin RSUD Kota Madiun. Desain penelitian ini menggunakan metode Pre-Eksperimental dengan pendekatan One Group pre-post test design, Sampel dalam penelitian ini berjumlah 16 pasien menggunakan teknik sampling purposive sampling. Berdasarkan dari hasil uji statistik paired t-test didapatkan ada pengaruh pemberian terapi musik klasik terhadap perubahan tingkat kecemasan pada pasien pre operasi sectio caesarea di ruang bersalin RSUD Kota Madiun

\section{METODE PENELITIAN}

Penelitian ini bertujuan untuk mengetahui pengaruh musik semar pegulingan terhadap tingkat kecemasan pasien pre operasi di ruang persiapan Siloam Hospitals Bali. Penelitian merupakan penelitian kuantitatif eksperimental dengan desain true eksperimental pretest-posttest with kontrol, sampel seluruh pasien pre operasi di ruang persiapan Siloam Hospitals Bali dengan lokal anastesi sesuai dengan kriteria inklusi dan ekslusi yang dipilih dengan cara purposive sampling sejumlah 32 pasien yang terdiri dari 16 kelompok kontrol dan 16 kelompok intervensi. Data dianalisis dengan uji nonparametric Uji Mann Whitney pada tingkat kemaknaan a 0.05.

\section{HASIL DAN PEMBAHASAN}

\section{Karakteristik Responden}

Dari 32 responden yang diteliti didapatkan sebaran karakteristik sebagian besar responden berada pada rentang usia > 55 tahun yaitu sebanyak 11 (34.4\%) 
responden. Sebagian besar responden berpendidikan S1 yaitu sebanyak 14 (43.8\%) responden.

\section{Kecemasan Pasien Pre Oprasi di Ruang Persiapan Siloam Hospitals Bali Sebelum Mendengarkan Musik Semar pegulingan}

Tabel 1

Kecemasan Pasien Pre Oprasi Sebelum Mendengarkan Musik Semar pegulingan

\begin{tabular}{ccc}
\hline Kecemasan Pre Test & Mean & Min - Max \\
\hline Kelompok Kontrol & 21.81 & $16-22$ \\
\hline Kelompok Intervensi & 21.12 & $15-25$ \\
\hline
\end{tabular}

Berdasarkan tabel di atas diketahui dari 16 responden yang diteliti pada kelompok kontrol didapatkan skor kecemasan paling rendah yaitu 16 dan skor paling tinggi 22 dengan rerata skor kecemasan 21.81 atau masuk dalam kategori kecemasan sedang. Dari 16 responden yang diteliti pada kelompok intervensi didapatkan skor kecemasan paling rendah yaitu 15 dan skor paling tinggi 25 dengan rerata skor kecemasan pasien pre oprasi di ruang persiapan Siloam Hospitals Bali sebelum mendengarkan musik semar pegulingan adalah 21.12 atau masuk dalam kategori kecemasan sedang

Kecemasan Pasien Pre Oprasi di Ruang Persiapan Siloam Hospitals Bali Setelah Mendengarkan Musik Semar pegulingan

Tabel 2

Kecemasan Pasien Pre Oprasi Setelah Mendengarkan Musik Semar pegulingan

\begin{tabular}{ccc} 
Kecemasan Post Test & Mean & Min - Max \\
\hline Kelompok Kontrol & 18.50 & $12-22$ \\
\hline Kelompok Intervensi & 15.75 & $12-19$ \\
\hline
\end{tabular}

Berdasarkan tabel di atas diketahui dari 16 responden yang diteliti pada kelompok kontrol didapatkan skor kecemasan terendah yaitu 12 dan skor tertinggi 22 dengan rerata skor kecemasan 18.50 atau berada pada kategori kecemasan ringan. Dari 16 responden yang diteliti pada kelompok intervensi didapatkan skor terendah 12 dan tertinggi 19 dengan rerata skor kecemasan pasien pre operasi di ruang persiapan
Siloam Hospitals Bali setelah mendengarkan musik semar pegulingan adalah 15.75 yang berada pada kategori kecemasan ringan.

\section{Uji Wilcoxon Signed Rang Test}

Tabel 3

Pengaruh Musik Semar pegulingan Terhadap Tingkat Kecemasan Pasien

\begin{tabular}{|c|c|c|c|c|}
\hline & \multicolumn{2}{|c|}{ Skor Kecemasan } & \multirow{2}{*}{$\mathrm{Z}$} & \multirow{2}{*}{$\mathrm{p}$} \\
\hline & & Mean & & \\
\hline \multirow{2}{*}{ Kontrol } & Pre & 21.81 & \multirow{2}{*}{-3.432} & \multirow{2}{*}{0.001} \\
\hline & Post & 18.50 & & \\
\hline \multirow{3}{*}{ Intervensi } & Pre & 21.12 & \multirow{3}{*}{-3.536} & \multirow{3}{*}{0.000} \\
\hline & & & & \\
\hline & Post & 15.75 & & \\
\hline
\end{tabular}

Hasil uji wilcoxon signed rang test pengaruh musik semar pegulingan terhadap tingkat kecemasan pasien pre operasi di ruang persiapan Siloam Hospitals Bali pada tingkat kemaknaan a 0.05 didapatkan nilai p sebesar $<0.05$ pada kelompok kontrol dan intervensi. Hal tersebut menunjukkan bahwa terdapat perbedaan tingkat kecemasan pasien pre operasi di ruang persiapan Siloam Hospitals Bali pada kelompok kontrol dan intervensi sebelum dan setelah diberikan terapi musik semar pegulingan.

\section{Hasil Uji Statistik Mann-Whitney Test}

Tabel 4

Pengaruh Musik Semar pegulingan Terhadap Tingkat Kecemasan Pasien

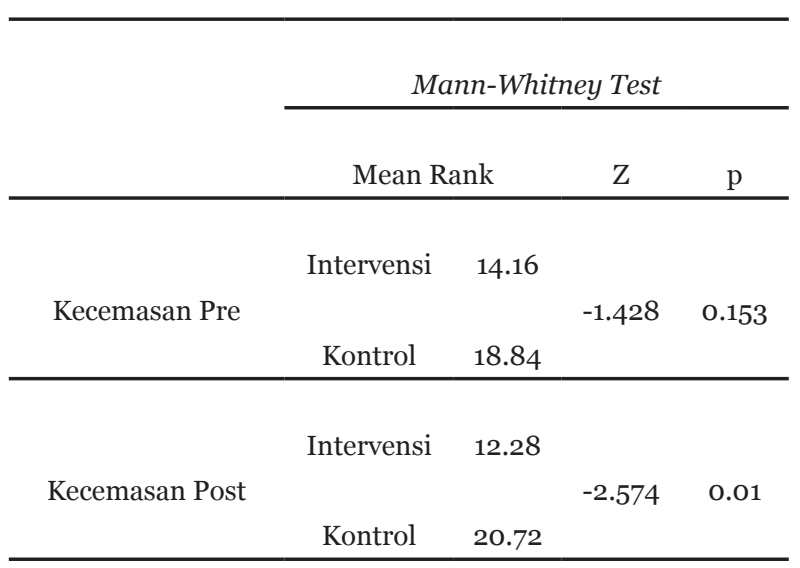


Dari hasil uji Mann - Whitney Test pengaruh musik semar pegulingan terhadap tingkat kecemasan pasien pre operasi di ruang persiapan Siloam Hospitals Bali pada tingkat kemaknaan a 0.05 didapatkan nilai p (o.153) > 0.05 yang menunjukkan bahwa tidak terdapat perbedaan kecemasan pada kelompok intervensi dan kontrol sebelum diberikan terapi musik semar pegulingan. Sementara setelah diberikan terapi musik semar pegulingan diperoleh nilai $\mathrm{p}(0.01)<0.05$ yang menunjukkan bahwa terdapat perbedaan kecemasan pada kelompok intervensi dan kontrol setelah diberikan terapi musik semar pegulingan, dengan nilai rerata skor kecemasan yang lebih rendah pada kelompok intervensi.

Tabel 5

Perbedaan Selisih Tingkat Kecemasan antara Kelompok Kontrol dan Intervensi pada Pasien Pre Operasi di Ruang Persiapan Siloam Hospitals Bali

\begin{tabular}{ccccc}
\hline Variabel & Kelompok & Mean & $\begin{array}{c}\text { Beda } \\
\text { Rerata }\end{array}$ & pvalue \\
& & & & \\
Selisih & Kontrol & 20.72 & & \\
\cline { 2 - 3 } $\begin{array}{c}\text { Tingkat } \\
\text { Kecemasan }\end{array}$ & Intervensi & 12.28 & & 0.014 \\
\hline
\end{tabular}

Berdasarkan tabel 5 dapat dilihat perbedaan selisih tingkat kecemasan antara kelompok kontrol dan intervensi pada pasien pre operasi di Ruang Persiapan Siloam Hospitals Bali, dimana nilai rerata kecemasan yang didapatkan pada kelompok kontrol sebesar 20.7 dan 12.28 pada kelompok intervensi dengan beda rerata sebesar 8.44 dimana nilai $p$ value 0.010 $<$ 0.05. Hasil ini menunjukkan adanya perbedaan selisih rerata skor kecemasan pada kelompok kontrol setelah disitirahatkan dengan kelompok intervensi setelah diperdengarkan musik semar pegulingan

\section{SIMPULAN DAN SARAN}

Terapi musik semar pegulingan dapat menurunkan tingkat kecemasan pasien pre operasi di Ruang Persiapan Siloam Hospitals Bali p (0.01) < $\alpha(0,05)$. Diharapkan tenaga kesehatan khususnya perawat dapat memahami dan mampu memberikan edukasi terkait terapi musik semar pegulingan pada pasien guna menurunkan kecemasan yang dirasakan oleh pasien khususnya kecemasan pada pasienpre operasi.

\section{DAFTAR PUSTAKA}

Abdullah, R. (2015). Gambaran Tingkat Kecemasan Dan Intervensi Keperawatan Dalam Menurunkan Tingkat Kecemasan Pasien Pre Operasi Di Bangsal Bedah Rsud Panembahan Senopati Bantul. Retrieved from http://repository.stikesayaniyk.ac.id/2718/2/ Rajib Abdullah_211036_nonfull.pdf

Amurwani, F. S. (2018). Faktor Penyebab Penundaan Operasi Elektif di Rumah Sakit Pemerintah Di Semarang. Jurnal Ilmu Keperawatan Medikal Bedah, 1(1), 17. https://doi.org/10.32584/jikmb. v1i1.95

Angkasa, M. P. (2018). Efektifitas Pemberian Konseling Keperawatan Terhadap Penurunan Tingkat Kecemasan Pasien Pre Operasi Mayor (Besar) Di Ruang Mawar Rsud Kajen Kabupaten Pekalongan. Jurnal Ilmu Keperawatan Medikal Bedah, 1(1), 8. https://doi.org/10.32584/jikmb.v1i1.94

Apriansyah, A. (2015). Hubungan Antara Tingkat Kecemasan Pre-Operasi dengan Derajat Nyeri Pada Pasien Post Sectio Caesarea di Rumah Sakit Muhammadiyah Palembang Tahun 2014. Jurnal Keperawatan Sriwijaya, 2(1), 1-7.

Atwater, F. H. (2001). Binaural beats and the regulation of arousal levels. Proceedings of the IANS 11th Forum on New Arts and Science Fort Collins Colo International Association on New Science.

Gabela, E. (2014). Analisis Fraktal Sinyal Berbagai Jenis Musik. II(3), 67-73.

Ganong, W. F. (2012). W. F. Ganong - Review of Medical Physiology. In Ganong's review of medical physiology.

Hawari, D. (2011). Manajemen Stres Cemas dan Depresi. In Balai Penerbit FKUI.

Hayati, F. (2017). Pengaruh pemberian terapi musik klasik terhadap tingkat kecemasan pada wanita menopause di wilayah pisangan, ciputat timur, tangerang selatan. Keperawatan, 5(8), 11-12. Idham Muhammad. (2010). Gambaran Kecemasan 
Pada Siswa/I Kelas XII SMAN 22 Bandung Menjelang UAN (Ujian Akhir Nasional). Fakultas Kedokteran Universitas Kristen Maranatha. Retrieved from http://weekly.cnbnews.com/news/ article.html?no=12400o

Kasana, N. (2018). Hubungan antara komunikasi terapeutik dengan tingkat kecemasan pada pasien pre operasi sectio caesarea di ruang ponek rsud karanganyar. Skripsi Kesehatan Komunikasi Terapeutik Dengan Tingkat Kecemasan STIKes Kusuma Husada, 17.

Kautsar, F., Gustopo, D., \& Achmad, F. (2015). Uji Validitas dan Reliabilitas Hamilton Anxiety Rating Scale Terhadap Kecemasan dan Produktivitas Pekerja Visual Inspection PT. Widatra Bhakti. Seminar Nasional Teknologi 2015. https://doi.org/10.1017/ CBO9780511792458

Kemenkes RI. (2018). Hasil Utama Riset Kesehatan Dasar 2018. Kementrian Kesehatan Republik Indonesia. https://doi.org/1 Desember 2013

Kustiawan, R. (2013). Kecemasan Pasien Pre Operasi Bedah Mayor.

Mertosono, N. (2015). Dampak Pembatalan dan Penundaan Operasi Elektif Terhadap Utilisasi Kamar Operasi di Instalasi Bedah Sentral Rumah Sakit Umum Pusat Persahabatan Jakarta. S2 Ilmu Kesehatan Masyarakat, 1-9.

Negoro, W. R. (2017). Pengaruh Musik Klasik dalam Menurunkan Tingkat Kecemasan Pasien Sectio Caesarea dengan Tindakan Subarachnoid Blok (SAB) di RSU Mitra Delima Malang, Jawa Timur. POLITEKNIK KESEHATAN.

Notoatmodjo, S. (2012). Metodologi Penelitian Ilmu Keperawatan. In Jakarta: Salemba Merdeka.

Nursalam. (2015). Metodelogi penelitian keperawatan. Pendekatan Praktis.Jakarta: Salemba Medika.

Nursalam. (2017). Metodologi Penelitian Ilmu Keperawatan. In Salemba Medika.
Paryanto. (2017). "Perbedaan Tingkat Kecemasan Pasien Pre Operatif Selama Menunggu Jam Operasi Antara Ruang Rawat Inap dengan Ruang Persiapan Operasi Rumah Sakit Ortopedi Surakarta. Universitas Muhammadiyah Surakarta, 2(5), 255. Retrieved from ???

Rahayu, A. S. (2017). Pengaruh Pemberian Terapi Musik Klasik Terhadap Perubahan Tingkat Kecemasan Pada Pasien Pre Operasi Sectio Caesarea Di Ruang Bersalin Di RSUD Kota Madiun. STIKES Bhakti Husada Mulai Madiun, 1(1), 287-295. https://doi.org/10.1016/j.sbspro.2015.04.758

Rahmayati, E. (2018). Pengaruh Dukungan Spritual terhadap Tingkat Kecemasan pada Pasien PreOperasi. Jurnal Kesehatan, 9(1), 138. https://doi. org/10.2663o/jk.v9i1.778

Riswanti, A. (2015). Hubungan Kecemasan dan Perilaku Terhadap Prestasi Belajar Mahasiswa Pendidikan Biologi Angkatan 2013 Uin Alauddin Makassar.

Sadock, Benjamin James; Sadock, Virginia Alcott; Ruiz, P. (2013). Kaplan \& Sadock's Synopsis of Psychiatry. In Journal of Chemical Information and Modeling. https://doi.org/10.1017/ CBO9781107415324.004

Sarwono, S. W. (2011). Psikologi Remaja Edisi Revisi. In Psikologi Remaja. https://doi. org/10.1108/09513551011032482.Bastian

Saryono. (2013). Metodelogi Penelitian Kualitatif dan Kuantitatif. In Medical Book. https://doi. org/10.1007/978-1-4939-2572-8_13

Setianing, S. (2019). Perubahan Kecemasan Pasien Pra Operasi Dengan Pemberian Komunikasi Terapeutik Metode Helping Relationship. JURNAL PENDIDIKAN KESEHATAN, 8(1), 50-57.

Stuart, G. W. (2016). Prinsip dan Praktik KEPERAWATAN KESEHATAN JIWA. In International Journal of Social Psychiatry. https:// doi.org/10.1177/0020764016675888 
sugiyono. (2016). metode penelitian pendidikan (kuantitatif kualitatif dan R \& D). Bandung: Alfabeta. https://doi.org/10.1164/rccm.200409-1267OC

Sugiyono. (2015). Metode Penelitian. Metode Penelitian.

Sulastri. (2019). Pengaruh Komunikasi Terapeutik Perawat terhadap Tingkat Kecemasan pada Pasien Pre Operasi. Jurnal Keperawatan Profesional (JKP), 7.

Suliswati, dkk. (2014). Konsep Dasar Keperawatan Kesehatan Jiwa. Pengaruh Terapi Reminiscence Terhadap Harga Diri Lansia.

Sumardi. (2019). Pengaruh Nafas Dalam Dan Mendengarkan Musik Gamelan Terhadap Tingkat Nyeri Pasien Post Operasi Fraktur Di RSUD Dr. Soediran Mangun Sumarso Wonogiri. 1o(1).

Suprajitno. (2016). Pengantar riset keperawatan. In Pusdik SDM Kesehatan.

Suswanti. (2019). Hubungan Pengetahuan Perioperatif Dengan Tingkat Kecemasan Pasien Pre Operasi Katarak Di Rs Mata “ Dr. Yap ” Yogyakarta. Fakultas Ilmu Kesehatan Universitas "Aisyiyah Yogyakarta.

Waryanuarita, I. (2017). Pengaruh Pemberian Terapi Musik Terhadap Kecemasan Pasien Pre General Anestesi di RS PKU Muhammadiyah Yogyakarta. Politeknik Kesehatan.

Wayan Indra Diatmika, Gede Mahendra Darmawiguna, Made Gede Sunarya. (2015). Pengembangan Aplikasi Instrumen Gamelan Semar Pengulingan Berbasis Android. Kumpulan Artikel Mahasiswa Pendidikan Teknik Informatika (KARMAPATI).

Widyastut, Y. (2015). Gambaran Kecemasan pada Pasien Pre Operasi Fraktur Femur di Rs Ortopedi Prof. Dr.R Soeharso Surakarta. 12, 31-36.

Wisuda, L. B. (2018). Pengaruh Terapi Musik Terhadap Penurunan Tingkat Kecemasan Pasien Pre Operasi Di RSUD dr Sayidiman Magetan. (March).
Witriya, C. (2016). Hubungan Tingkat Kecemasan dengan Pola Tidur Lansia di Kelurahan Tlogomas Kota Malang. Nursing News: Jurnal Ilmiah Mahasiswa Keperawatan, 1 No. 2, 190-203. Retrieved from https://publikasi.unitri.ac.id/index. $\mathrm{php} /$ fikes/article/view/437

Yulinda, L. D. (2014). Perbedaan Efektifitas Terapi Musik Klasik dan Relaksasi Nafas Dalam Terhadap Penurunan Kecemasan Pasien di Ruang HCU. 16-44. Retrieved from http://repository.ump. ac.id/146/3/BAB II_Lintiya Devi Y..pdf 